\title{
Halothiobacillus kellyi sp. nov., a mesophilic, obligately chemolithoautotrophic, sulfur- oxidizing bacterium isolated from a shallow- water hydrothermal vent in the Aegean Sea, and emended description of the genus Halothiobacillus
}

\author{
Stefan M. Sievert, Thorsten Heidorn and Jan Kuever
}

Author for correspondence: Jan Kuever. Tel: +49 4212028 734. Fax: +494212028580. e-mail: jkuever@mpi-bremen.de

Department of

Microbiology, Max-PlanckInstitute for Marine Microbiology, Celsiusstraße 1, D-28359 Bremen, Germany

\begin{abstract}
A new mesophilic, chemolithoautotrophic, sulfur-oxidizing bacterium, strain Milos-BII1 ${ }^{\top}$, was isolated from a sediment sample taken from a shallow-water hydrothermal vent in the Aegean Sea with thiosulfate as electron donor and $\mathrm{CO}_{2}$ as carbon source. Based on the almost complete sequence of the 165 rRNA gene, strain Milos-BII1' forms a phylogenetic cluster with Thiobacillus hydrothermalis, Thiobacillus neapolitanus, Thiobacillus halophilus and Thiobacillus sp. W5, all of which are obligately chemolithoautotrophic bacteria. Because of their phylogenetic relatedness and their physiological similarities it is proposed to transfer these organisms to a newly established genus within the $\gamma$-subclass of the Proteobacteria, Halothiobacillus gen. nov. (Kelly and Wood 2000). Strain Milos-BII1 ${ }^{\top}$ represents a new species of this genus, named Halothiobacillus kellyi. Cells were Gram-negative rods and highly motile. The organism was obligately autotrophic and strictly aerobic. Nitrate was not used as electron acceptor. Chemolithoautotrophic growth was observed with thiosulfate, tetrathionate, sulfur and sulfide. Growth was observed between pH values of 3.5 and 8.5, with an optimum at pH 6.5. The temperature limits for growth were 3.5 and $49{ }^{\circ} \mathrm{C}$, with an optimum between 37 and $42{ }^{\circ} \mathrm{C}$. Growth occurred between 0 and $2 \mathrm{M} \mathrm{NaCl}$, with an optimum $\mathrm{NaCl}$ concentration between 400 and $500 \mathrm{mM}$. The mean maximum specific growth rate on thiosulfate was $0.45 \mathrm{~h}^{-1}$.
\end{abstract}

Keywords: Thiobacillus, Halothiobacillus, sulfur-oxidizing bacteria, hydrothermal vent

\section{INTRODUCTION}

The genus Thiobacillus contains a wide range of Gramnegative, rod-shaped, colourless sulfur bacteria, which have in common the ability to use reduced sulfur compounds as electron donor for autotrophic growth (Kelly \& Harrison, 1989; Kuenen et al., 1992). In contrast to the original description of an obligately

Abbreviations: DTNB, 5,5'-dithio-bis(2-nitrobenzoic acid); MPN, most probable number.

The GenBank accession numbers for the nearly complete 165 rRNA sequences of strain Milos-BII1 ${ }^{\top}$ and Halothiobacillus neapolitanus (formerly Thiobacillus neapolitanus) are AF170419 and AF173169, respectively. autotrophic, sulfur-oxidizing organism given by Beijerinck (Beijerinck, 1904; Beijerinck \& Minkman, 1910) several species growing heterotrophically or mixotrophically have also been named Thiobacillus because they could use reduced sulfur compounds as electron donors and produced sulfate as end product. The different physiological properties and the range of DNA base composition (45-70 $\mathrm{mol} \% \mathrm{G}+\mathrm{C}$ ) already indicated the need for a reclassification of members of this genus. This was even more obvious after the sequence data for the 16S rRNA genes showed that the species of Thiobacillus fall into the $\alpha-, \beta$ - and $\gamma$ subclasses of the Proteobacteria (Lane et al., 1992). Since then, several species of this genus have been 
reclassified (Katayama et al., 1995; Moreira \& Amils, 1997; Hiraishi et al., 1998). Because of their phylogenetic relatedness and their physiological similarities, Kelly \& Wood (2000) proposed the transfer of Thiobacillus hydrothermalis, Thiobacillus neapolitanus and Thiobacillus halophilus to a new genus within the $\gamma$ subclass of the Proteobacteria, Halothiobacillus gen. nov. In this paper, we describe a new species of a marine, obligately chemolithoautotrophic, sulfuroxidizing bacterium which, based on phylogenetic and physiological data, belongs to the genus Halothiobacillus. Together with Halothiobacillus hydrothermalis, its closest relative, this is the second example of a chemolithoautotrophic, sulfur-oxidizing bacterium isolated from a marine hydrothermal vent system which does not belong to the genus Thiomicrospira. In addition, the complete 16S rDNA sequence of Halothiobacillus neapolitanus (formerly Thiobacillus neapolitanus), the type strain of the proposed genus Halothiobacillus, was determined because the earlier sequence was incomplete.

\section{METHODS}

A mineral medium with $20 \mathrm{mM}$ thiosulfate (added by sterile filtration to the autoclaved medium) as sole electron donor was used for enrichment, isolation and routine culture work. The composition of the mineral medium (TB medium) (in $\mathrm{g} \mathrm{l}^{-1}$ ) was: $\mathrm{NaCl}(29),\left(\mathrm{NH}_{4}\right)_{2} \mathrm{SO}_{4}(1), \mathrm{MgSO}_{4} \cdot 7 \mathrm{H}_{2} \mathrm{O}(1 \cdot 5)$, $\mathrm{CaCl} .2 \mathrm{H}_{2} \mathrm{O}(0 \cdot 42), \mathrm{K}_{2} \mathrm{HPO}_{4}(0 \cdot 5), \mathrm{KCl}(0 \cdot 7)$, vitamin $\mathrm{B}_{12}$ $(0 \cdot 00005)$, with trace element solution containing EDTA (Widdel \& Bak, 1992) $\left(1 \mathrm{ml} \mathrm{l}^{-1}\right)$. Bromothymol blue was added as $\mathrm{pH}$ indicator at a concentration of $4 \mathrm{mg} \mathrm{l}^{-1}$. $\mathrm{K}_{2} \mathrm{HPO}_{4}$ was autoclaved separately and added to the medium after autoclaving.

Isolation of bacteria. Most probable number (MPN) estimates and enrichment cultures were obtained by inoculating medium with $1 \mathrm{~cm}^{3}$ sediment from a shallow-water hydrothermal vent system located in the Bay of Palaeochori, Milos, Greece. A detailed description of the MPN counting procedure, the sampling site and the prevailing environmental conditions was given by Sievert et al. (1999). The cultures were incubated at $22^{\circ} \mathrm{C}$ in the dark to avoid growth of phototrophic bacteria. After growth had occurred, as indicated by a change in the colour of the $\mathrm{pH}$ indicator and by sulfur deposition, $1 \mathrm{ml}$ culture was transferred to $10 \mathrm{ml}$ fresh medium. For isolation of pure cultures, $0 \cdot 1 \mathrm{ml}$ aliquots of the enrichment cultures were transferred onto thiosulfate agar plates and repeatedly streaked out. Colonies were transferred at least three times to be considered pure.

Growth experiments. Batch cultures were grown in $500 \mathrm{ml}$ flasks containing $100 \mathrm{ml}$ medium on a rotary shaker at $30^{\circ} \mathrm{C}$ in the dark. Routine cultivation of the isolates and utilization of different substrates were investigated in $15 \mathrm{ml}$ tubes containing $10 \mathrm{ml}$ mineral medium. Large-scale cultivation was done in 3 and 201 glass carboys supplied with $40 \mathrm{mM}$ thiosulfate, in which the $\mathrm{pH}$ was monitored by a sterilized $\mathrm{pH}$ electrode (Ingold) and readjusted by titration with $\mathrm{Na}_{2} \mathrm{CO}_{3}(1 \mathrm{M})$ through a personal computer program controlling a peristaltic pump. The program was developed by V. Meyer at the Max-Planck-Institute for Marine Microbiology, Bremen, Germany.

The maximum specific growth rate in thiosulfate medium was determined at 22 and $37^{\circ} \mathrm{C}$ by direct counts [DAPI $(4,6-$ diamidino-2-phenylindole) staining and epifluorescence microscopy; Porter \& Feig, 1980], increase in optical density (at $420 \mathrm{~nm}$ ) or protein concentration. Protein was determined by the Coomassie brilliant blue dye binding technique (Bradford, 1976) using a Bio-Rad protein assay kit. Growth kinetics on thiosulfate in continuous cultures were determined in home-made chemostats. The $\mathrm{pH}$ was controlled and adjusted as indicated above. Dissolved oxygen was supplied in excess at $50-100 \%$ air saturation. The oxygen concentration was monitored by an autoclavable oxygen electrode (Ingold) and adjusted via magnetic valves controlled by the same computer program as indicated above.

Estimates of the optimal $\mathrm{pH}$ value for growth of the new isolate and the lowest and highest $\mathrm{pH}$ values tolerated were determined by using medium adjusted to different initial $\mathrm{pH}$ values $(3 \cdot 5-10 \cdot 0)$. A colour change of the $\mathrm{pH}$ indicator upon acidification indicated growth. The optimal $\mathrm{pH}$ was determined by measuring the oxygen consumption rate at different $\mathrm{pH}$ values. The chemostat was equilibrated under substrate limitation at a dilution rate, $D$, of $0 \cdot 1 \mathrm{~h}^{-1}\left(22^{\circ} \mathrm{C}\right.$, $\mathrm{pH} 7 \cdot 0$ ). The addition of substrate was stopped, the dissolved oxygen concentration adjusted to $100 \%$ air saturation and the desired $\mathrm{pH}$ value of the medium adjusted. The cells were then supplied with fresh medium at $D=0 \cdot 4 \mathrm{~h}^{-1}$ and the oxygen consumption rate was determined. This procedure was carried out for each $\mathrm{pH}$ value from 5.0 to 8.0 at 0.5 unit intervals.

The optimal growth temperature of the new isolate was determined in a thermally insulated aluminium block which was heated electrically to $+60{ }^{\circ} \mathrm{C}$ at one end and cooled to $+3.5^{\circ} \mathrm{C}$ with a refrigerated circulation thermostat at the other end. The block contained 30 rows of 4 holes, so that samples could be incubated simultaneously at temperature intervals of $1.5{ }^{\circ} \mathrm{C}$ with a maximum of four replicates. The temperature limits of growth were established by screening for acidification for $10 \mathrm{~d}$. The optimal growth temperature was determined within $24 \mathrm{~h}$ after inoculation.

The $\mathrm{NaCl}$ requirement and tolerance of the isolates were tested in medium supplied with $20 \mathrm{mM}$ sodium thiosulfate containing varying $\mathrm{NaCl}$ concentrations (in $\mathrm{M}: 0,0 \cdot 2,0 \cdot 4$, $0 \cdot 55,0 \cdot 8,1 \cdot 0,2 \cdot 0,2 \cdot 5$ and $3 \cdot 0$ ) and incubated at $30^{\circ} \mathrm{C}$.

Utilization of inorganic electron donors. The ability to oxidize and grow on different reduced sulfur compounds was tested by using TB medium supplemented with one of the following compounds: thiosulfate $(20 \mathrm{mM})$, tetrathionate $(10 \mathrm{mM})$, sulfite $(1,3,5,10$ and $20 \mathrm{mM})$, thiocyanate $(1,3,5$ and $10 \mathrm{mM})$ and elemental sulfur $(0 \cdot 1 \%$, $\mathrm{w} / \mathrm{v})$. The sulfite stock solution was prepared in $50 \mathrm{mM}$ EDTA to prevent autooxidation. Substrate utilization and product formation was monitored according to Rethmeier et al. (1997). Sulfite oxidation was tested with a solution of Ellman's reagent [5,5'-dithio-bis(2-nitrobenzoic acid); DTNB] $\left(1 \mathrm{~g}^{-1}\right.$ in $50 \mathrm{mM}$ potassium phosphate buffer $\mathrm{pH} 7 \cdot 0$ ). DTNB is reduced by sulfite and thiol groups to a yellow-coloured product (maximum absorbance at $412 \mathrm{~nm}$ ). Growth on sulfide was determined by using $0 \cdot 2 \%(\mathrm{w} / \mathrm{v})$ slush agar gradients over $8 \mathrm{mM}$ sulfide-containing agar plugs (Nelson \& Jannasch, 1983). Uninoculated controls showed no $\mathrm{pH}$ change and no turbidity.

Autotrophic growth on hydrogen was tested on solid mineral medium supplied with bicarbonate $(30 \mathrm{mM})$ incubated in a jar containing a gas mixture of $80 \% / 20 \%$ (v/v) hydrogen/ air and in liquid media (Nishihara et al., 1989).

Anaerobic growth. The use of nitrate as an electron acceptor in the absence of oxygen was tested under autotrophic and 
heterotrophic conditions by using bicarbonate $(30 \mathrm{mM})$ buffered medium supplied with $20 \mathrm{mM} \mathrm{KNO}_{3}$ and prepared anaerobically. Hungate tubes contained $10 \mathrm{ml}$ liquid medium under a $90 \% / 10 \%(\mathrm{v} / \mathrm{v}), \mathrm{N}_{2} / \mathrm{CO}_{2}$ gas phase and the various electron donors indicated above.

Utilization of organic electron donors. Heterotrophic growth was checked in TB medium without $\mathrm{pH}$ indicator supplied with one of the following compounds: fructose $(5 \mathrm{mM})$, glucose $(5 \mathrm{mM})$, formate $(20$ and $40 \mathrm{mM})$, acetate $(20 \mathrm{mM})$, pyruvate $(10 \mathrm{mM})$, lactate $(10 \mathrm{mM})$, Casamino acids $(0 \cdot 1$ and $0.01 \%, \mathrm{w} / \mathrm{v})$, peptone $(0 \cdot 1$ and $0.01 \%, \mathrm{w} / \mathrm{v})$ and yeast extract $(0.1$ and $0.01 \%, \mathrm{w} / \mathrm{v})$. The same additions in TB medium with bromothymol blue containing $20 \mathrm{mM}$ thiosulfate were used for testing for an inhibitory effect of organic compounds on thiosulfate oxidation.

Ubiquinone analysis. The ubiquinone fraction was isolated, purified and identified by B. Tindall (DSMZ Identification Service, Braunschweig, Germany) from cells harvested from large-scale cultures as described previously (Brinkhoff et al., 1999a).

DNA base composition. For determining the $\mathrm{G}+\mathrm{C}$ content, cells were disrupted and the DNA purified on hydroxyapatite (Cashion et al., 1977). The DNA was hydrolysed with P1 nuclease and the nucleotides dephosphorylated with bovine alkaline phosphatase (Mesbah et al., 1989). The resulting deoxyribonucleosides were analysed by HPLC according to Tamaoka \& Komagata (1984). The instrument was calibrated with non-methylated lambda DNA (Sigma; $\mathrm{G}+\mathrm{C}$ content $49.86 \mathrm{~mol} \%$ ). The $\mathrm{G}+\mathrm{C}$ content was calculated from the ratio of deoxyguanosine $(\mathrm{dG})$ and deoxyadenosine (dA) at the DSMZ (Braunschweig, Germany) (Mesbah et al., 1989).

PCR amplification and sequencing of the 16S rRNA gene. To amplify the almost complete 16S rRNA encoding gene (1500 bp) of strains MT-96, M40/2 CIV-2.3 and M40/2 CIV-3.2, primers GM3F and GM4R were used in a 35-cycle PCR with an annealing temperature of $40^{\circ} \mathrm{C}$. PCR products were purified by using the QIAquick Spin PCR purification kit (Qiagen) as described by the manufacturer. The Taq Dyedeoxy Terminator Cycle Sequencing kit (Applied Biosystems) was used to directly sequence the PCR products according to the protocol provided by the manufacturer. The sequencing primers were as described by BuchholzCleven et al. (1997). The sequence reaction mixtures were electrophoresed on an Applied Biosystems 373S DNA sequencer.

Comparative analysis of 16S rRNA sequences. The 16S rRNA sequences used in this study were: Thiomonas thermosulfata ATCC $51520^{\mathrm{T}}$ (U17839), Thiomonas cuprina DSM 5495 (U67162), Acidiphilium acidophilum DSM 700 ${ }^{\mathrm{T}}$ (D86511), Thiobacillus thioparus DSM 505 ${ }^{\mathrm{T}}$ (M79426), Thiobacillus thiooxidans DSM 504 (M79396, M79397, M79398), Thiobacillus ferrooxidans DSM 583 ${ }^{\mathrm{T}}$ (M79404, M79405, M79406), Thiobacillus caldus DSM 8584 ${ }^{\mathrm{T}}$ (Z29975), Thiobacillus tepidarius DSM 3134 ${ }^{\mathrm{T}}$ (M79399, M79419, M79420), Thiomonas perometabolis ATCC 23370 ${ }^{\mathrm{T}}$ (M79399, M79400), Thiobacillus novellus DSM 506 ${ }^{\mathrm{T}}$ (D32247), Thiobacillus sp. W5 (X97534), Halothiobacillus halophilus DSM 6132 (U58020), H. hydrothermalis DSM 7121 ${ }^{\mathrm{T}}$ (M90662), H. neapolitanus DSM 581 ${ }^{\mathrm{T}}$ (M79418, M79419, 79420). Sequences that were not included in the 16S rRNA sequence database ARB of the Technical University Munich (O. Strunk and others, http://www.mikro.biologie.tu. muenchen.de) were added from databases. The tool $\mathrm{ARB}_{-}$ align was used for sequence alignment. The alignment was checked by eye and corrected manually. Tree topologies were evaluated by performing maximum-parsimony, neighbourjoining and maximum-likelihood analysis. Only at least $90 \%$ complete sequences were used for the calculation of different trees. Partial sequences were inserted into the reconstructed tree by applying the parsimony criteria without allowing for changes in the overall tree topology.

\section{RESULTS}

\section{Isolation of strain Milos-BII1 ${ }^{\top}$}

Pure cultures were obtained by subculturing single colonies of the lowest dilution of the MPN series and from enrichments. After sequencing of the 16S rRNA genes of these isolates, it became obvious that they were all identical, but showed less than $93 \%$ similarity to all described Thiobacillus spp. (see Table 1). Several identical strains were obtained from different zones and sediment depths, indicating widespread occurrence at the vent site. However, Thiobacillus spp. were only isolated from the low dilutions of the MPN series, which could also be seen as enrichment cultures. The higher dilutions of the series lead to the isolation of other sulfur-oxidizing bacteria, for example Thiomicrospira spp. (Brinkhoff et al., 1999b). One isolate, Milos B-II $1^{\mathrm{T}}$, originating from sediment underlying a white precipitate (sediment layer $0-5 \mathrm{~mm}$ ) that formed at a specific region around the vent site (Sievert et al., 1999) was used for further characterization. The in situ temperature in this zone increased from $22{ }^{\circ} \mathrm{C}$ at the sediment surface to almost $50{ }^{\circ} \mathrm{C}$ at $5 \mathrm{~cm}$ sediment depth; the in situ $\mathrm{pH}$ was about 6.0-7.0 at the sediment surface and remained constant at about 5.5 in the sediment (Sievert et al., 1999).

\section{Morphology}

Cells of strain Milos-BII ${ }^{\mathrm{T}}$ appeared singly or in pairs as motile rods $0.4-0.6 \mu \mathrm{m}$ in width and $1.2-2.5 \mu \mathrm{m}$ in length. The isolate was Gram-negative and sporeformation was absent.

\section{Growth conditions}

The isolate was strictly aerobic and grew autotrophically on thiosulfate, tetrathionate, sulfur and sulfide, but not on thiocyanate. Growth on thiosulfate lowered the $\mathrm{pH}$ from neutrality to $2 \cdot 8-3 \cdot 0$. Thiosulfate was completely oxidized to sulfate, with a recovery of 90-99\%. Formation of elemental sulfur was observed on solid media and in liquid media. Sulfite was oxidized to sulfate if the concentration in the medium did not exceed $3 \mathrm{mM}$. EDTA alone showed no toxic effect. In controls without bacteria, sulfite remained present as indicated by the reduction of DTNB. No growth occurred in medium supplemented with any of the organic substrates tested. Oxidation of thiosulfate was not inhibited by any of the organic substrates. Nitrate was not used as a terminal electron acceptor. Hydrogen 
Table 1. Similarity values for the $16 \mathrm{~S}$ rRNA sequences of Halothiobacillus sp. Milos-B $I 11^{\top}$ and other micro-organisms originally classified as Thiobacillus

\begin{tabular}{|c|c|c|c|c|c|c|c|c|c|c|c|c|c|c|c|}
\hline Strain & 1 & 2 & 3 & 4 & 5 & 6 & 7 & 8 & 9 & 10 & 11 & 12 & 13 & 14 & 15 \\
\hline $\begin{array}{l}\text { 1. Tm. perometabolis } \\
\text { ATCC } 23370^{\mathrm{T}}\end{array}$ & - & & & & & & & & & & & & & & \\
\hline $\begin{array}{l}\text { 2. Tm. thermosulfata } \\
\text { ATCC } 51520^{\mathrm{T}}\end{array}$ & $95 \cdot 0$ & - & & & & & & & & & & & & & \\
\hline 3. Tm. cuprina DSM $5495^{\mathrm{T}}$ & $93 \cdot 7$ & $93 \cdot 8$ & - & & & & & & & & & & & & \\
\hline 4. Tb. thioparus DSM $505^{\mathrm{T}}$ & $87 \cdot 7$ & $87 \cdot 7$ & $89 \cdot 0$ & - & & & & & & & & & & & \\
\hline 5. Thiobacillus sp. W5 & $85 \cdot 7$ & $83 \cdot 1$ & $82 \cdot 9$ & $83 \cdot 4$ & - & & & & & & & & & & \\
\hline $\begin{array}{l}\text { 6. Ht. hydrothermalis } \\
\text { DSM } 7121^{\mathrm{T}}\end{array}$ & $85 \cdot 3$ & $83 \cdot 4$ & 83.6 & $84 \cdot 3$ & $90 \cdot 2$ & - & & & & & & & & & \\
\hline 7. Tb. thiooxidans DSM $504^{\mathrm{T}}$ & $83 \cdot 0$ & $82 \cdot 3$ & $82 \cdot 6$ & $83 \cdot 2$ & $84 \cdot 1$ & $83 \cdot 8$ & - & & & & & & & & \\
\hline 8. Tb. ferrooxidans DSM $583^{\mathrm{T}}$ & $83 \cdot 8$ & $84 \cdot 0$ & $84 \cdot 1$ & $83 \cdot 9$ & $84 \cdot 5$ & $84 \cdot 5$ & $98 \cdot 2$ & - & & & & & & & \\
\hline 9. Tb. caldus DSM $8584^{\mathrm{T}}$ & $83 \cdot 2$ & $82 \cdot 5$ & $82 \cdot 7$ & $83 \cdot 9$ & $83 \cdot 6$ & $84 \cdot 5$ & $94 \cdot 8$ & $96 \cdot 3$ & - & & & & & & \\
\hline 10. Tb. tepidarius DSM $3134^{\mathrm{T}}$ & $83 \cdot 7$ & $82 \cdot 8$ & $83 \cdot 1$ & $83 \cdot 5$ & $84 \cdot 3$ & $83 \cdot 6$ & $90 \cdot 2$ & $90 \cdot 7$ & $89 \cdot 6$ & - & & & & & \\
\hline 11. Tb. novellus DSM $506^{\mathrm{T}}$ & $83 \cdot 0$ & $81 \cdot 1$ & $81 \cdot 0$ & $80 \cdot 3$ & $81 \cdot 1$ & $81 \cdot 1$ & $80 \cdot 4$ & $82 \cdot 6$ & $80 \cdot 1$ & $82 \cdot 1$ & - & & & & \\
\hline 12. Ap. acidophilum DSM $700^{\mathrm{T}}$ & $83 \cdot 2$ & $82 \cdot 7$ & $83 \cdot 0$ & $82 \cdot 0$ & $83 \cdot 7$ & $84 \cdot 2$ & $83 \cdot 5$ & $84 \cdot 4$ & $84 \cdot 0$ & $82 \cdot 6$ & $85 \cdot 3$ & - & & & \\
\hline 13. Ht. halophilus DSM $6132^{\mathrm{T}}$ & $85 \cdot 2$ & $83 \cdot 1$ & $83 \cdot 3$ & $84 \cdot 1$ & $90 \cdot 1$ & $98 \cdot 7$ & $83 \cdot 8$ & $84 \cdot 3$ & $84 \cdot 4$ & $83 \cdot 5$ & $81 \cdot 0$ & $83 \cdot 7$ & - & & \\
\hline 14. Ht. sp. Milos-BII1 ${ }^{\mathrm{T}}$ & $87 \cdot 5$ & $84 \cdot 9$ & $85 \cdot 1$ & $83 \cdot 5$ & $91 \cdot 7$ & $93 \cdot 4$ & $84 \cdot 2$ & $85 \cdot 2$ & $85 \cdot 1$ & $84 \cdot 4$ & $81 \cdot 7$ & $84 \cdot 2$ & $93 \cdot 0$ & - & \\
\hline 15. Ht. neapolitanus DSM $581^{\mathrm{T}}$ & $85 \cdot 8$ & $83 \cdot 3$ & $83 \cdot 5$ & $83 \cdot 4$ & $98 \cdot 5$ & $90 \cdot 8$ & $84 \cdot 3$ & $85 \cdot 0$ & $83 \cdot 8$ & $84 \cdot 5$ & $81 \cdot 2$ & $83 \cdot 7$ & $90 \cdot 6$ & $92 \cdot 2$ & - \\
\hline
\end{tabular}

was not used as an electron donor for autotrophic growth. Addition of vitamin $\mathrm{B}_{12}$ was not essential for growth. Maximum specific growth rates on thiosulfate at $37^{\circ} \mathrm{C}$ and at optimal $\mathrm{pH}$ were obtained from the mean of three different procedural determinations, i.e. direct counts, optical density and protein production. Growth in batch cultures with $20 \mathrm{mM}$ thiosulfate showed a maximum specific growth rate $\left(\mu_{\max }\right)$ of $0.4 \mathrm{~h}^{-1}$ at $\mathrm{pH} 6.5$ and $37^{\circ} \mathrm{C}$, whereas the rate at $\mathrm{pH} 7.0$ and $22^{\circ} \mathrm{C}$ was $0 \cdot 25-0.3 \mathrm{~h}^{-1}$. The maximum specific growth rate in chemostat cultures with $20 \mathrm{mM}$ thiosulfate was estimated from washout kinetics after raising the dilution rate of the culture in steady state from $0 \cdot 2$ to $0 \cdot 4$. At $\mathrm{pH} 7 \cdot 0$ and $22{ }^{\circ} \mathrm{C}$, the $\mu_{\max }$ was between $0 \cdot 25$ and $0 \cdot 3$. Under optimal conditions $(\mathrm{pH}$ 6.5 and $37^{\circ} \mathrm{C}$ ) the values for $\mu_{\max }$ estimated from washout kinetics were in the range $0 \cdot 5-0 \cdot 6$. The rates were nearly the same for $100 \%$ and $20 \%$ air-saturated medium.

The $\mathrm{pH}$ range for growth of strain Milos-BII1 ${ }^{\mathrm{T}}$ on thiosulfate was between 3.5 and $8 \cdot 5$. At a $\mathrm{pH}$ of $9 \cdot 0$, no growth was observed.

The temperature range for growth was between 3.5 and $49{ }^{\circ} \mathrm{C}$, with an optimum between 37 and $42^{\circ} \mathrm{C}$. Growth was determined by measurement of acidification of the medium over a period of $10 \mathrm{~d}$.

The isolate showed no specific requirement for $\mathrm{NaCl}$ (0-2 M), although best growth occurred at $\mathrm{NaCl}$ concentrations between 400 and $500 \mathrm{mM}$. Nevertheless, it should be noted that the medium without $\mathrm{NaCl}$ contained at least $40 \mathrm{mM} \mathrm{Na}{ }^{+}$from the addition of sodium thiosulfate.

\section{DNA base ratio and ubiquinone content}

The $\mathrm{G}+\mathrm{C}$ content of strain Milos-BII1 ${ }^{\mathrm{T}}$ was $62 \pm 0.2 \mathrm{~mol} \%$. The isolate contained Q-8 as the only major ubiquinone.

\section{Phylogenetic analysis}

Similarity matrix values and phylogenetic affiliation are shown in Table 1 and Fig. 1, respectively. Comparison of the nearly complete $16 \mathrm{~S}$ rRNA genes showed that strain Milos-BII1 ${ }^{\mathrm{T}}$ belongs to the $\gamma$ subclass of the Proteobacteria and exhibits less than $93.4 \%$ similarity to all other described Thiobacillus spp. The closest relative is $H$. hydrothermalis with a value of $93.4 \%$. The new, nearly complete sequence of the 16S rDNA gene from $H$. neapolitanus corresponded well with previous results obtained with the incomplete sequence (Kelly \& Wood, 2000).

\section{DISCUSSION}

Strain Milos-BII1 ${ }^{\mathrm{T}}$ is a chemolithoautotrophic, sulfuroxidizing bacterium. Based on the almost complete sequence of the 16S rRNA gene, it forms a phylogenetic cluster with $H$. hydrothermalis, H. neapolitanus, H. halophilus and Thiobacillus sp. W5 (Fig. 1), which are also obligately chemolithoautotrophic. The similarity values of the 16S rRNA sequences for the new isolate as listed in Table 1 are below $97 \%$. According to the definition of Stackebrandt \& Goebel (1994), this itself indicates that strain Milos-BII $1^{\mathrm{T}}$ does not belong to a presently described species. In addition, although strain Milos-BII1 ${ }^{\mathrm{T}}$ shares many physiological proper- 


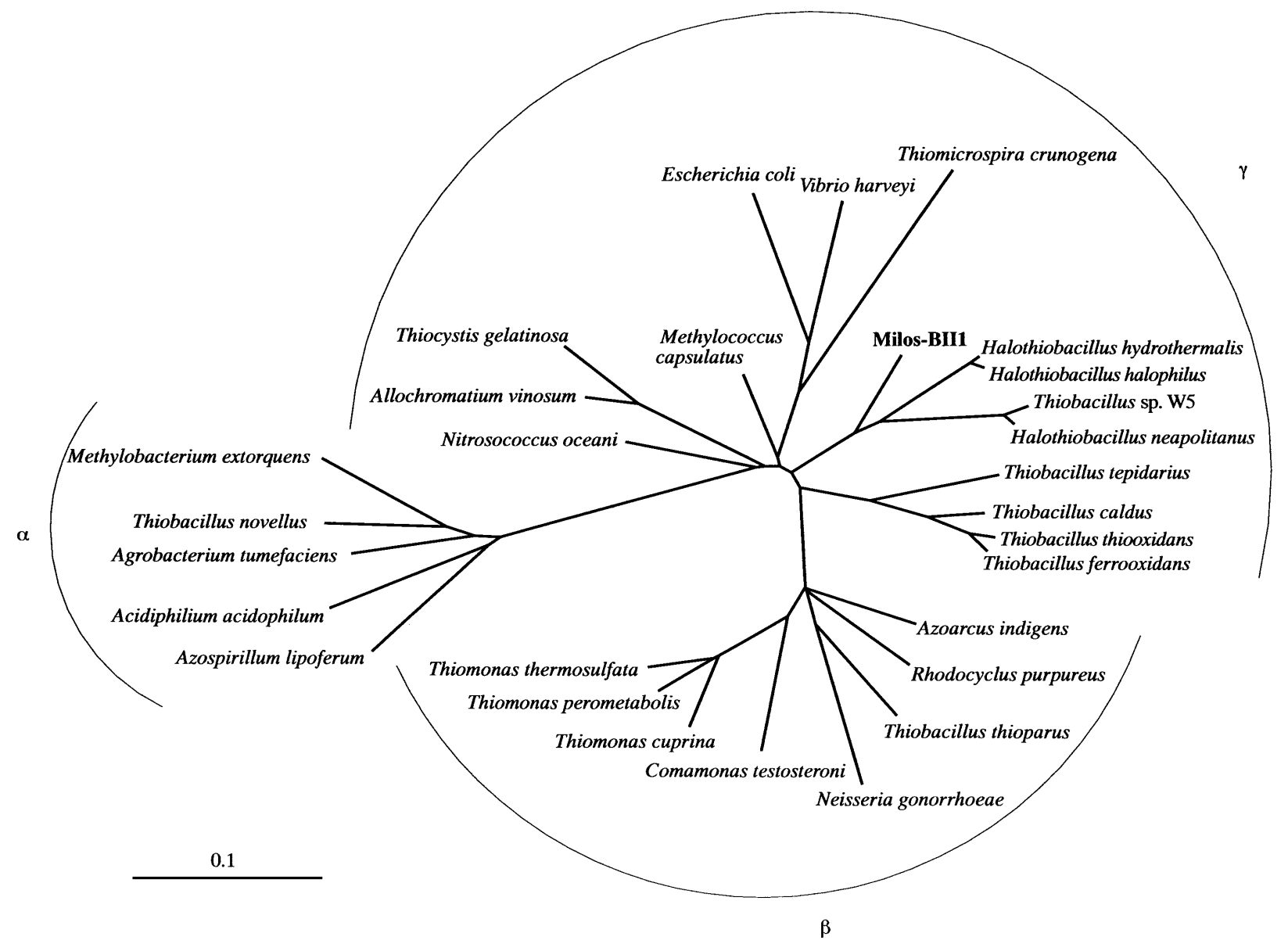

Fig. 1. Maximum-likelihood tree based on 1308 positions of nearly full-length $16 \mathrm{~S}$ rRNA sequences from 23 bacteria, using the $\alpha$-subclass of the Proteobacteria as an outgroup. Trees constructed with other reconstruction algorithms (neighbour-joining and parsimony) resulted in the same overall topology. In bootstrap analysis using neighbour-joining and parsimony criteria, the branching of the proposed Halothiobacillus cluster was supported with values of 100 . Partial sequences of Acidiphilium acidophilum, Thiomonas thermosulfata, Thiomonas perometabolis, Thiomonas cuprina, Thiobacillus ferrooxidans, Thiobacillus thiooxidans and Thiobacillus tepidarius were inserted into the tree by applying parsimony criteria without allowing for changes in the overall topology. Bacteria of the $\alpha-, \beta$ - and $\gamma$-subclasses of the Proteobacteria are indicated by ' $\alpha$ ', ' $\beta^{\prime}$ and ' $\gamma^{\prime}$, respectively. The sequences of Halothiobacillus sp. Milos-BIII' and Halothiobacillus neapolitanus (Parker strain $\mathrm{X}^{\top}$ ) were determined in this study.

ties with $H$. hydrothermalis, there are distinct differences (Table 2). For example, the $\mathrm{pH}$ optimum and the lower $\mathrm{pH}$ limit for growth are shifted to lower values. This might indicate an adaptation to a more acidic environment (Sievert et al., 1999). Therefore, we propose that the isolate can be considered as a new species within the aforementioned cluster.

\section{Ecological significance}

From its growth characteristics, strain Milos-BII1 ${ }^{\mathrm{T}}$ seemed to be well adapted to the environment from which it was isolated. However, it was apparently not among the dominant sulfur-oxidizing bacteria in this habitat. It was not isolated from the highest dilutions of MPN series that showed positive growth. Instead, other sulfur-oxidizing bacteria, for example Thiomicrospira strains Milos T-1 and T-2 (Brinkhoff et al., 1999b), were isolated. In addition, Thiomicrospira populations could be detected in a denaturing gradient gel electrophoresis (DGGE) analysis of the bacterial community (Brinkhoff et al., 1999b), whereas no DGGE bands were found that exhibited the same electrophoretic behaviour as the 16S rDNA fragment of strain Milos-BII1 ${ }^{\mathrm{T}}$ (S. M. Sievert, unpublished data). Results obtained from a competition experiment carried out in a chemostat between strain Milos-BII $1^{\mathrm{T}}$ and Thiomicrospira strain Milos T-2 indicated that Thiomicrospira strain Milos T-2 was superior to strain Milos-BII $1^{\mathrm{T}}$ at high dilution rates, i.e. $D>1.7 \mathrm{~h}^{-1}$. In contrast, at low dilution rates, i.e. low substrate concentrations, strain Milos-BII $1^{\mathrm{T}}$ displaced Thiomicrospira strain Milos T-2 (unpublished data). In relation to the actual environment, this might indicate that the sulfur-oxidizing bacterial community was not limited by substrate availability in situ. This seems 
Table 2. Morphological and physiological characteristics among Halothiobacillus spp.

All species were obligately chemolithotrophic motile rods; oxidized sulfide, sulfur, thiosulfate and tetrathionate, but not thioisocyanate; did not use nitrate as a terminal electron acceptor; and contained ubiquinone Q-8. Data were obtained from Hutchinson et al. (1965, 1969); Smith \& Kelly (1979); Kelly \& Harrison (1989); Durand et al. (1993); Wood \& Kelly (1991); McDonald et al. (1997); Visser et al. (1997); Kelly et al. (1998); and own results. ND, Not determined.

\begin{tabular}{|c|c|c|c|c|c|}
\hline Character & $\begin{array}{c}\text { Halothiobacillus sp. } \\
\text { Milos-BII1 }^{\mathrm{T}}\end{array}$ & $\begin{array}{l}\text { H. hydrothermalis } \\
\text { DSM } 7121^{\mathrm{T}}\end{array}$ & $\begin{array}{l}\text { H. halophilus } \\
\text { DSM 6132 }\end{array}$ & $\begin{array}{l}\text { H. neapolitanus } \\
\text { DSM 581 }\end{array}$ & $\begin{array}{c}\text { Thiobacillus sp. } \\
\text { W5 }\end{array}$ \\
\hline Width $(\mu \mathrm{m})$ & $0 \cdot 4-0 \cdot 6$ & $0 \cdot 4-0.5$ & $0 \cdot 3-0 \cdot 5$ & $0 \cdot 3-0 \cdot 5$ & $0 \cdot 5$ \\
\hline Length $(\mu \mathrm{m})$ & $1 \cdot 2-2 \cdot 5$ & $1 \cdot 2-1 \cdot 5$ & $1 \cdot 0-1 \cdot 2$ & $1 \cdot 0-1 \cdot 5$ & $1 \cdot 0-1 \cdot 5$ \\
\hline $\mathrm{G}+\mathrm{C}$ content $(\mathrm{mol} \%)$ & $62 \cdot 0$ & $67 \cdot 4$ & $64 \cdot 2$ & $56 \cdot 0$ & $56 \cdot 0$ \\
\hline $\begin{array}{l}\text { Maximum specific growth } \\
\text { rate on thiosulfate }\left(\mathrm{h}^{-1}\right)\end{array}$ & $0 \cdot 45$ & $0 \cdot 6$ & ND & $0 \cdot 28$ & ND \\
\hline Optimum pH & $6 \cdot 5$ & $7 \cdot 5-8 \cdot 0$ & $7 \cdot 0-7 \cdot 3$ & $6 \cdot 5-6 \cdot 9$ & $7 \cdot 0-7 \cdot 5$ \\
\hline $\mathrm{pH}$ range for growth & $3 \cdot 5-8 \cdot 5$ & $6 \cdot 0-9 \cdot 0$ & ND & $4 \cdot 5-8 \cdot 5$ & $3 \cdot 5-8 \cdot 5$ \\
\hline $\begin{array}{l}\text { Lowest } \mathrm{pH} \text { produced in } \\
\text { thiosulfate medium }\end{array}$ & $2 \cdot 8$ & $4 \cdot 8$ & $5 \cdot 5-6 \cdot 0$ & $2 \cdot 8$ & ND \\
\hline Optimum temperature $\left({ }^{\circ} \mathrm{C}\right)$ & $37-42$ & $35-40$ & $30-32$ & $28-32$ & $25-30$ \\
\hline Maximum temperature $\left({ }^{\circ} \mathrm{C}\right)$ & $48-49$ & $48-49$ & $35-36$ & 39 & 42 \\
\hline $\mathrm{NaCl}$ requirement & - & - & + & - & ND \\
\hline $\begin{array}{l}\text { Optimal } \mathrm{NaCl} \\
\text { concentration }(\mathrm{mM})\end{array}$ & $400-500$ & 430 & $800-1000$ & ND & ND \\
\hline $\mathrm{NaCl}$ tolerance $(\mathrm{mM})$ & 2500 & 2000 & 4000 & $>860$ & ND \\
\hline
\end{tabular}

reasonable considering a constant resupply of reduced sulfur compounds by the expelled hydrothermal fluid. Another possible explanation might be a limitation of iron or other metals caused by the formation of metal sulfides as a result of high sulfide levels at the vent site. In chemostat studies under iron-limiting conditions, Thiomicrospira pelophila outcompeted Thiobacillus thioparus (Kuenen et al., 1977). Both observations could also provide an explanation for the prevalence of Thiomicrospira at hydrothermal vent systems in general (Ruby et al., 1981; Ruby \& Jannasch, 1982; Jannasch et al., 1985; Muyzer et al., 1995; Brinkhoff et al., 1999b). However, more studies are required to confirm these hypotheses, for example by varying other relevant environmental parameters in the chemostat and by enumeration of the respective cells with culture-independent techniques such as fluorescent in situ hybridization (FISH). Since both organisms fall into coherent phylogenetic clusters, the design of specific probes should be feasible. It is interesting to note that at the hydrothermal vent system in the Fiji Basin, both $H$. hydrothermalis and Thiomicrospira spp. were present (Durand et al., 1994).

\section{Similarities between $H$. neapolitanus, $H$. hydrothermalis, H. halophilus and strain Milos-BII1 ${ }^{\top}$}

As has already been reported in previous publications on the taxonomic position of various Thiobacillus spp., there is a high level of physiological and phylogenetic similarity between $H$. neapolitanus, $H$. hydrothermalis and H. halophilus (McDonald et al., 1997; Kelly et al., 1998). As shown in Fig. 1, all these organisms form a monophyletic group within the $\gamma$-subclass of the
Proteobacteria as supported by a bootstrap value of 100 and can clearly be distinguished from other strains of the genus belonging to the same subgroup or to the $\gamma$ - and $\beta$-subclasses of the Proteobacteria (McDonald et al., 1997). The identity of the different species was confirmed by DNA-DNA hybridization for organisms showing a high level of similarity at the 16S rRNA gene level (Kelly et al., 1998). The organism described in this paper and another obligate chemolithoautotrophic sulfur-oxidizing bacterium tentatively named Thiobacillus sp. W5 (Visser et al., 1997) are phylogenetically and physiologically closely related to these species (see Tables 1 and 2), although some data and a formal description of the latter is lacking. Combining the available physiological data on all species belonging to this cluster, it becomes obvious that they share several properties. They are all motile, obligately chemolithoautotrophic, sulfur-oxidizing bacteria containing ubiquinone Q-8. A very unusual feature compared to other Thiobacillus spp. is the $\mathrm{NaCl}$ tolerance of all species and a $\mathrm{NaCl}$ requirement of some species. H. neapolitanus has not been shown to have a strict $\mathrm{NaCl}$ requirement, but it tolerates high $\mathrm{NaCl}$ concentrations of more than $860 \mathrm{mM}$. The available data in this respect for Thiobacillus sp. W5 are lacking. Because of the phylogenetic and physiological relatedness of the aforementioned organisms, it was suggested that they are transferred to the new genus Halothiobacillus to clarify the confused taxonomic situation within the genus Thiobacillus (Kelly \& Wood, 2000). The new, nearly complete $16 \mathrm{~S}$ rDNA sequences obtained in the present study confirm the results already obtained by McDonald et al. (1997) and Kelly et al. (1998). The proposal by Kelly \& Wood 
(2000) for the new genus Halothiobacillus to accommodate the halotolerant, obligately chemolithoautotrophic organisms $T$. neapolitanus, $T$. halophilus and $T$. hydrothermalis is justified with respect to our data. Their proposal to designate $H$. neapolitanus (NCIMB $8539^{\mathrm{T}}$, DSM $581^{\mathrm{T}}$ ) as the type species of the genus Halothiobacillus is appropriate. It was the first species to be described and was the subject of many early studies on the oxidation of reduced sulfur compounds by autotrophic organisms. In addition, historical reasons should be considered because Nathansohn (1902) isolated a very similar organism from the Bay of Naples, Italy. H. neapolitanus is also well suited to reflect the halotolerance of most species of this genus.

\section{Emended description of the genus Halothiobacillus (Kelly and Wood 2000)}

Halothiobacillus (Hal.o.thi.o.ba.cil'lus. Gr. n. hals sea, salt; Gr. n. thios sulfur; L. n. bacillus a small rod; L. masc. n. Halothiobacillus salt-loving sulfur rodlet).

Cells are rod-shaped, $0.3-0.6 \mu \mathrm{m}$ in diameter and $1 \cdot 0-2.5 \mu \mathrm{m}$ in length. They are Gram-negative, occur singly or in pairs and are motile. Spore formation is absent. All members of the genus are strictly aerobic and grow chemolithoautotrophically with thiosulfate, tetrathionate, sulfur and sulfide, but not with thiocyanate, as electron donor, and with carbon dioxide as carbon source. Heterotrophic growth is never observed. Addition of acetate can increase the amount of biomass produced if a reduced sulfur compound is provided as electron donor. Sulfate is the end product of sulfur compound oxidation, but sulfur, sulfite or polythionates may be accumulated, sometimes transiently, by most species. During growth on reduced sulfur compounds, the $\mathrm{pH}$ decreases from neutrality to a $\mathrm{pH}$ as low as 2.5-3.0 depending on the species. Optimal growth occurs between $\mathrm{pH} 6.5$ and 8.0 at temperatures of $30-42{ }^{\circ} \mathrm{C}$. The optimal $\mathrm{NaCl}$ concentration for growth is $400-500 \mathrm{mM}$ for most strains, but many tolerate much higher concentrations. A requirement for $\mathrm{NaCl}$ is found for some species. Carbon dioxide is fixed by means of ribulose-bisphosphate carboxylase. Nitrate can be reduced to nitrite, but is not reduced further. On thiosulfate agar, cells produce small, white-yellowish, smooth, entire colonies $(1-3 \mathrm{~mm}$ in diameter) in which sulfur is deposited and acid is produced. Ubiquinone Q-8 is present in the respiratory chain. The $\mathrm{G}+\mathrm{C}$ content of the DNA of members of this genus varies between 56 and $67 \mathrm{~mol} \%$. As determined by $16 \mathrm{~S}$ rRNA gene sequence analysis, the genus Halothiobacillus belongs to the $\gamma$-subclass of the Proteobacteria. Members of the genus can be isolated from freshwater, soil and frequently from marine environments. Traditional enrichment culture techniques seem to favour their isolation because of their higher acid tolerance compared to other marine, sulfur-oxidizing bacteria such as Thiomicrospira spp. The type species is Halo- thiobacillus neapolitanus (formerly Thiobacillus neapolitanus) strain NCIMB $8539^{\mathrm{T}}\left(=\mathrm{DSM} 581^{\mathrm{T}}=\right.$ Parker strain $\mathrm{X}^{\mathrm{T}}$ ).

\section{Description of Halothiobacillus kellyi}

Halothiobacillus kellyi (kel'ly.i. M.L. gen. n. kellyi of Kelly; named after Donovan P. Kelly, a British microbiologist who has made important contributions to research on sulfur-oxidizing bacteria and their physiology).

Cells are Gram-negative, motile and rod-shaped $(0 \cdot 4$ $0.6 \times 1 \cdot 2-2.5 \mu \mathrm{m})$. They are strictly aerobic and grow autotrophically on thiosulfate, tetrathionate, sulfur and sulfide, but not on thiocyanate. Sulfite is oxidized to sulfate if the concentration does not exceed $3 \mathrm{mM}$. The organism does not grow heterotrophically. When thiosulfate is used as the primary energy source a transient formation of sulfur occurs. During growth on reduced sulfur compounds, the $\mathrm{pH}$ decreases from neutrality to around $2 \cdot 8$. Thiosulfate is completely oxidized to sulfate. Autotrophic growth on thiosulfate occurs between $\mathrm{pH} 3.5$ and 8.5 and at temperatures of $3.5-49{ }^{\circ} \mathrm{C}$; optimum growth occurs at $\mathrm{pH} 6.5$ and at $37-42^{\circ} \mathrm{C}$. The optimal $\mathrm{NaCl}$ concentration for growth is $0.4-0.5 \mathrm{mM}$; growth is possible between $\mathrm{NaCl}$ concentrations of 0 and $2 \mathrm{M}$. Nitrate is not used as terminal electron acceptor. The mean maximum specific growth rate on thiosulfate is $0.45 \mathrm{~h}^{-1}$. On thiosulfate agar, cells produce white-yellowish, smooth, entire colonies (diameter on $1.2 \%$ agar is $1-4 \mathrm{~mm}$ ) in which sulfur is deposited and acid is produced. Ubiquinone Q-8 is present in the respiratory chain. The $\mathrm{G}+\mathrm{C}$ content of the DNA is $62 \mathrm{~mol} \%$. As determined by $16 \mathrm{~S}$ rRNA gene sequence analysis, the organism belongs to the $\gamma$-subclass of the Proteobacteria and is closely related to other members of this genus. The type strain is Milos-BII1 ${ }^{\mathrm{T}}$, which was isolated from a marine shallow-water hydrothermal vent system and is deposited at the Deutsche Sammlung von Mikroorganismen und Zellkulturen, Braunschweig, Germany, under accession number DSM 13162. The GenBank accession number for the nearly complete $16 \mathrm{~S}$ rRNA gene sequence of $H$. kellyi is AF170419.

\section{ACKNOWLEDGEMENTS}

The authors thank I. Kunze, J. V. Meyer, J. Rethmeier, S. Schübbe and H. G. Trüper for advice and help, and F. O. Glöckner for introducing us to ARB. We are indebted to D. P. Kelly and A. P. Wood for advice, help and access to their unpublished manuscript on the genus Thiobacillus. We are grateful to Susanne Menger, Guido Lützenkirchen and Wiebke Ziebis for scuba diving and sampling, and the mechanical workshop of the MPI for building the sampling devices. Special thanks goes to the participants of the EUfunded project 'Hydrothermal Fluxes and Biological Production in the Aegean' for their various support and help. We also acknowledge the kind permission of the Greek authorities for scuba diving and fieldwork. This work was 
funded by the EU under MAST CT-95-0021 and the MaxPlanck-Society, Munich (Germany).

\section{REFERENCES}

Beijerinck, M. W. (1904). Ueber die Bakterien, welche sich im Dunkeln mit Kohlensäure als Kohlenstoffquelle ernähren können. Zentbl Bakteriol Abt II 11, 593-599.

Beijerinck, M. W. \& Minkman, D. C. (1910). Bildung und Verbrauch von Stickoxydul durch Bakterien. Zentbl Bakteriol Abt II 25, 30-63.

Bradford, M. M. (1976). A rapid and sensitive method for quantitation of microgram quantities of protein utilizing the principle of protein-dye binding. Anal Biochem 72, 248-254.

Brinkhoff, T., Muyzer, G., Wirsen, C. O. \& Kuever, J. (1999a). Thiomicrospira kuenenii sp. nov. and Thiomicrospira frisia $\mathrm{sp}$. nov., two mesophilic obligately chemolithotrophic sulfur-oxidizing bacteria isolated from an intertidal mud flat. Int $J$ Syst Bacteriol 49, 385-392.

Brinkhoff, T., Sievert, S. M., Kuever, J. \& Muyzer, G. (1999b). Distribution and diversity of sulfur-oxidizing Thiomicrospira spp. at a shallow-water hydrothermal vent in the Aegean Sea (Milos, Greece). Appl Environ Microbiol 65, 3843-3849.

Buchholz-Cleven, B. E. E., Ratunde, B. \& Straub, K. L. (1997). Screening for genetic diversity of isolates of anaerobic Fe(II)oxidizing bacteria using DGGE and whole-cell hybridization. Syst Appl Microbiol 20, 301-309.

Cashion, P., Holder-Franklin, M. A., McCully, J. \& Franklin, M. (1977). A rapid method for the base ratio determination of bacterial DNA. Anal Biochem 81, 461-466.

Durand, P., Reysenbach, A.-L., Prieur, D. \& Pace, N. (1993). Isolation and characterization of Thiobacillus hydrothermalis sp. nov., a mesophilic obligately chemolithotrophic bacterium isolated from a deep-sea hydrothermal vent in Fiji Basin. Arch Microbiol 159, 39-44.

Durand, P., Benyagoub, A. \& Prieur, D. (1994). Numerical taxonomy of heterotrophic sulfur-oxidizing bacteria isolated from southwestern Pacific hydrothermal vents. Can J Microbiol 40, 690-697.

Hiraishi, A., Nagashima, K. V. P., Matsuura, K., Shimada, K., Takaichi, S., Wakao, N. \& Katayama, Y. (1998). Phylogeny and photosynthetic features of Thiobacillus acidophilus and related acidophilic bacteria: its transfer to the genus Acidiphilium as Acidiphilium acidophilum comb. nov. Int J Syst Bacteriol 48, 1389-1398.

Hutchinson, M., Johnstone, K. I. \& White, D. (1965). The taxonomy of certain Thiobacilli. J Gen Microbiol 41, 357-366.

Hutchinson, M., Johnstone, K. I. \& White, D. (1969). Taxonomy of the genus Thiobacillus: the outcome of numerical taxonomy applied to the group as a whole. J Gen Microbiol 57, 397-410.

Jannasch, H. W., Wirsen, C. O., Nelson, D. C. \& Robertson, L. A. (1985). Thiomicrospira crunogena sp. nov., a colorless sulfuroxidizing bacterium from a deep-sea hydrothermal vent. Int $J$ Syst Bacteriol 35, 422-424.

Katayama, Y., Hiraishi, A. \& Kuraishi, H. (1995). Paracoccus thiocyanatus sp. nov., a new species of thiocyanate-utilizing facultative chemolithotroph, and transfer of Thiobacillus versutus to the genus Paracoccus as Paracoccus versutus comb. nov. with emendation of the genus. Microbiology 141, 1469-1477.

Kelly, D. P. \& Harrison, A. P. (1989). Genus Thiobacillus Beijerinck. In Bergey's Manual of Systematic Bacteriology, 1st edn, vol. 3, pp. 1842-1858. Edited by J. T. Staley, M. P. Bryant, N. Pfennig \& J. G. Holt. Baltimore: Williams \& Wilkins.
Kelly, D. P. \& Wood, A. P. (2000). Reclassification of some species of Thiobacillus to the newly designated genera Acidithiobacillus gen. nov., Halothiobacillus gen. nov. and Thermithiobacillus gen. nov. Int J Syst Evol Microbiol 50, 511-516.

Kelly, D. P., Stackebrandt, E., Burghardt, J. \& Wood, A. P. (1998). Confirmation that Thiobacillus halophilus and Thiobacillus hydrothermalis are distinct species within the $\gamma$-subclass of the Proteobacteria. Arch Microbiol 170, 138-140.

Kuenen, J. G., Boonstra, J., Schröder, H. G. J. \& Veldkamp, H. (1977). Competition for inorganic substrates among chemoorganotrophic and chemolithotrophic bacteria. Microb Ecol 3, 119-130.

Kuenen, J. G., Robertson, L. A. \& Tuovinen, O. H. (1992). The genera Thiobacillus, Thiomicrospira, and Thiosphaera. In The Prokaryotes, 2nd edn, pp. 2638-2657. Edited by A. Balows, H. G. Trüper, M. Dworkin, W. Harder \& K.-H. Schleifer. New York: Springer.

Lane, D. L., Harrison, A. P., Stahl, D., Pace, B., Giovannoni, S. J., Olsen, G. J. \& Pace, R. (1992). Evolutionary relationships among sulphur- and iron-oxidizing eubacteria. $J$ Bacteriol 174, 269-278.

McDonald, I. R., Kelly, D. P., Murrell, J. C. \& Wood, A. P. (1997). Taxonomic relationships of Thiobacillus halophilus, Thiobacillus aquesulis, and other species of Thiobacillus, as determined using 16S rRNA sequencing. Arch Microbiol 166, 394-398.

Mesbah, M., Premachandran, U. \& Whitman, W. B. (1989). Precise measurement of the $\mathrm{G}+\mathrm{C}$ content of deoxyribonucleic acid by high-performance liquid chromatography. Int $J$ Syst Bacteriol 39, 159-167.

Moreira, D. \& Amils, R. (1997). Phylogeny of Thiobacillus cuprinus and other mixotrophic thiobacilli: proposal for Thiomonas gen. nov. Int J Syst Bacteriol 47, 522-528.

Muyzer, G., Teske, A., Wirsen, C. O. \& Jannasch, H. W. (1995). Phylogenetic relationships of Thiomicrospira species and their identification in deep-sea hydrothermal vent samples by denaturing gradient gel electrophoresis of $16 \mathrm{~S}$ rDNA fragments. Arch Microbiol 164, 165-172.

Nathansohn, A. (1902). Über eine neue Gruppe von Schwefelbacterien und ihren Stoffwechsel. Mitt Zool Stat Neapel 15, 655-680.

Nelson, D. C. \& Jannasch, H. W. (1983). Chemoautotrophic growth of a marine Beggiatoa in sulfide-gradient cultures. Arch Microbiol 136, 262-269.

Nishihara, H., Igararashi, Y. \& Kodama, T. (1989). Isolation of an obligately chemolithoautotrophic, halophilic and aerobic hydrogen-oxidizing bacterium from marine environment. Arch Microbiol 152, 39-42.

Porter, K. G. \& Feig, Y. S. (1980). The use of DAPI for identifying and counting aquatic microflora. Limnol Oceanogr 25, 943-948.

Rethmeier, J., Rabenstein, A., Langer, M. \& Fischer, U. (1997). Detection of traces of oxidized and reduced sulfur compounds in small samples by combination of different high-performance liquid chromatography methods. J Chromatogr A 760, 295-302.

Ruby, E. G. \& Jannasch, H. W. (1982). Physiological characteristics of Thiomicrospira sp. strain L-12 isolated from deep-sea hydrothermal vents. J Bacteriol 149, 161-165.

Ruby, E. G., Wirsen, C. O. \& Jannasch, H. W. (1981). Chemolithoautotrophic sulfur-oxidizing bacteria from the Galapagos Rift hydrothermal vents. Appl Environ Microbiol 42, 317-342.

Sievert, S. M., Brinkhoff, T., Muyzer, G., Ziebis, W. \& Kuever, J. (1999). Spatial heterogeneity of bacterial populations along an environmental gradient at a shallow submarine hydrothermal 
vent near Milos Island (Greece). Appl Environ Mircobiol 65, 3834-3842.

Smith, A. L. \& Kelly, D. P. (1979). Competition in the chemostat between an obligately and a facultatively chemolithotrophic Thiobacillus. J Gen Microbiol 115, 377-384.

Stackebrandt, E. \& Goebel, B. M. (1994). Taxonomic note: a place for DNA-DNA reassociation and 16S rRNA sequence analysis in the present species definition in bacteriology. Int $J$ Syst Bacteriol 44, 846-849.

Tamaoka, J. \& Komagata, K. (1984). Determination of DNA base composition by reversed-phase high-performance liquid chromatography. FEMS Microbiol Lett 25, 125-128.
Visser, J. M., Stefess, G. C., Robertson, L. A. \& Kuenen, J. G. (1997). Thiobacillus sp. W5, the dominant autotroph oxidizing sulfide to sulfur in a reactor for aerobic treatment of sulfidic wastes. Antonie Leeuwenhoek 72, 127-134.

Widdel, F. \& Bak, F. (1992). Gram-negative mesophilic sulfatereducing bacteria. In The Prokaryotes, 2nd edn, vol. IV, pp. 3352-3378. Edited by A. Balows, H. G. Trüper, M. Dworkin, W. Harder \& K.-H. Schleifer. New York: Springer.

Wood, A. P. \& Kelly, D. P. (1991). Isolation and characterisation of Thiobacillus halophilus sp. nov., a sulphur-oxidising autotrophic eubacterium from a Western Australian hypersaline lake. Arch Microbiol 156, 277-280. 